\title{
Cytotoxicity and the effect of cationic peptide fragments against cariogenic bacteria under planktonic and biofilm conditions
}

Paula Fernanda Kreling, Kelly Limi Aida, Loiane Massunari, Karina Sampaio Caiaffa, Célio Percinoto, Telma Blanca Lombardo Bedran, Denise Madalena Palomari Spolidorio, Gabriel Flores Abuna, Eduardo Maffud Cilli \& Cristiane Duque

To cite this article: Paula Fernanda Kreling, Kelly Limi Aida, Loiane Massunari, Karina Sampaio Caiaffa, Célio Percinoto, Telma Blanca Lombardo Bedran, Denise Madalena Palomari Spolidorio, Gabriel Flores Abuna, Eduardo Maffud Cilli \& Cristiane Duque (2016) Cytotoxicity and the effect of cationic peptide fragments against cariogenic bacteria under planktonic and biofilm conditions, Biofouling, 32:9, 995-1006, DOI: 10.1080/08927014.2016.1218850

To link to this article: https://doi.org/10.1080/08927014.2016.1218850

曲 Published online: 18 Aug 2016.

Submit your article to this journal $[\pi$

Џlll Article views: 241

View Crossmark data ¿

Citing articles: 11 View citing articles $\sqsubset$ 


\title{
Cytotoxicity and the effect of cationic peptide fragments against cariogenic bacteria under planktonic and biofilm conditions
}

\author{
Paula Fernanda Kreling ${ }^{a}$, Kelly Limi Aidaa, Loiane Massunarib, Karina Sampaio Caiaffa ${ }^{\mathrm{b}}$, Célio Percinoto ${ }^{\mathrm{a}}$, Telma \\ Blanca Lombardo Bedran`, Denise Madalena Palomari Spolidorioc, Gabriel Flores Abunad, Eduardo Maffud Cillie \\ and Cristiane Duque ${ }^{a}$
}

\begin{abstract}
aDepartment of Pediatric Dentistry and Public Health, Araçatuba Dental School, UNESP - Universidade Estadual Paulista, Araçatuba, São Paulo, Brazil; bepartment of Restorative Dentistry (Endodontics), Araçatuba Dental School, UNESP - Universidade Estadual Paulista, Araçatuba, São Paulo, Brazil; 'Department of Physiology and Pathology, Araraquara Dental School, UNESP - Universidade Estadual Paulista, Araraquara, São Paulo, Brazil; 'Department of Dental Materials, Piracicaba Dental School, UNICAMP - Universidade de Campinas, Piracicaba, São Paulo, Brazil; eDepartment of Biochemistry and Chemical Technology, Institute of Chemistry, UNESP - Universidade Estadual Paulista, Araraquara, São Paulo, Brazil
\end{abstract}

ABSTRACT

This study evaluated the cytotoxicity and effect of fragments derived from three oral cationic peptides (CP): LL-37, D6-17 and D1-23 against cariogenic bacteria under planktonic and biofilm conditions. For cytotoxicity analysis, two epithelial cell lines were used. The minimum inhibitory concentration and the minimal bactericidal concentration were determined for the CP fragments and the control (chlorhexidine- $\mathrm{CHX}$ ) against cariogenic bacteria. The fractional inhibitory concentration was obtained for the combinations of CP fragments on Streptococcus mutans. Biofilm assays were conducted with the best antimicrobial CP fragment against $S$. mutans. The results indicated that D6-17 was not cytotoxic. D1-23, LL-37 and CHX were not cytotoxic in low concentrations. D1-23 presented the best bactericidal activity against S. mutans, S. mitis and S. salivarius. Combinations of CP fragments did not show a synergic effect. D1-23 presented a higher activity against S. mutans biofilm than CHX. It was concluded that D1-23 showed a substantial effect against cariogenic bacteria and low cytotoxicity.

\section{ARTICLE HISTORY}

Received 24 April 2016

Accepted 25 July 2016

KEYWORDS

Dental caries; peptides; cell culture; biofilms

\section{Introduction}

Early childhood caries (ECC) represents the most common chronic disease in childhood with a prevalence of around 26\% in Brazil (SB Brasil 2010) and 23\% in the USA (Dye et al. 2015) among 5-6 year old children, and can be observed in toddlers as young as 12 months of age (SB Brasil 2010; Dye et al. 2015). ECC can progress and lead to severe destruction of primary teeth, causing infection, pain, chewing and speech difficulties, physiological trauma and early dental loss (Losso et al. 2009). Besides the negative effects on health, quality of life and high treatment costs, children who present ECC remain at a high risk for future caries recurrences and under continuous dental interventions, such as topical fluoride/antimicrobial applications (O’Sullivan \& Tinanoff 1996).

By virtue of rapid tooth destruction in a short period of time, the association between the following factors has been suggested in the etiology of ECC: frequent intake of a diet rich in fermentable carbohydrates such as sucrose, a high microorganism count and immunological vulnerability (Mattos-Graner et al. 1998, 2001). The bacterial group considered most cariogenic is mutans streptococci, especially Streptococcus mutans, one of the primary bacterial colonizers of dental enamel and less frequently Streptococcus sobrinus (van Houte et al. 1991; MattosGraner et al. 2001, 2014). However, other acidogenic and aciduric species, such as Lactobacillus and Actinomyces, are involved in the initiation of carious lesions (Sansone et al. 1993; van Houte et al. 1996).

The immune system has several forms of defense against pathogenic microorganisms. In addition to the physical barrier against the entrance of foreign microbes, mucous membranes are a source of potent antimicrobial cationic peptides (AMCP) (Mccormick \& Weinberg 2010). They have an inhibitory action against a broad range of bacteria, fungi and enveloped viruses and promote modulation 
of the host immune response while maintaining normal microbiota in different niches such as the skin, intestine and oral cavity (Mccormick \& Weinberg 2010; Wiesner \& Vilcinskas 2010). The main AMCP found in saliva and/or crevicular fluid are $\alpha$ - and $\beta$-defensins (hBD) and cathelicidins, produced by epithelial cells (Abiko et al. 2003). Studies have focused on the effect of hBD-3 against important oral pathogens, such as S. mutans, S. sobrinus, Fusobacterium nucleatum and Porphyromonas gingivalis (Ouhara et al. 2005). The human cationic peptide (hCAP18 ) is the only cathelicidin identified in humans, produced by epithelial cells from the lungs, gut, urogenital tract and oral cavity. After secretion, hCAP-18 is broken, by protease activity, to a small peptide called LL-37. This peptide fragment is a multifunctional immune modulator with antibacterial function and the ability to stimulate angiogenesis, skin healing and chemotaxis of inflammatory cells (Mccormick \& Weinberg 2010; Wiesner \& Vilcinskas 2010).

Limited research has been conducted to determine the effectiveness of synthetic or natural chemotherapeutic agents, individually or in combination, to prevent or reduce the incidence of ECC (Horowitz 1998). There has been recent interest in the use of peptides for the prevention of dental caries (da Silva et al. 2013; Benergossi et al. 2015). Although AMCP have been pointed out as a new class of antibiotics, the long length of their amino acid chain or chemical linkages make their production as a therapeutic agent difficult. These peptides could serve as a template for the design of effective antibiotics for oral application, potentially reducing the cost of production and optimizing their antimicrobial properties (Batoni et al. 2011). Synthetic analogs of AMCP have reached clinical trials to be indicated for patients, as reported for defensin mimetic PMX-30063 and histatin-5 P113 (Gordon et al. 2005). The aim of this study was to evaluate the cytotoxicity and the effect of fragments derived from three oral cationic peptides (CP): LL-37 (from hCAP-18), and D6-17 and D1-23 (from ortholog of $\beta$-defensin-3) against cariogenic bacteria under planktonic and biofilm conditions.

\section{Materials and methods}

\section{Preparation of peptides and controls}

The peptide fragments LL-3(LLGDFFRKSKEKIGK EFKRIVQRIKDFLRNLVPRTES) derived from hCAP-18 (Ji et al. 2007); Def14-1C $\mathrm{C}^{\mathrm{V}}$ (6-17) or D6-17 (LRKFFARIRGGR) and Defb14-1C ${ }^{\mathrm{V}}$ (1-23) or D1-23 (FLPKTLRKFFARI RGGRAAVLNA) derived from Defb14, the mouse ortholog of human $\beta$-defensin-3 (Reynolds et al. 2010), were purchased from Invitrogen (Life Technologies, Carlsbad, CA, USA). Defb $14-1 \mathrm{C}^{\mathrm{V}}$ is a peptide in which the cysteines have been replaced with alanines, except $\mathrm{Cys}_{40}$, which resides at position $\mathrm{V}$ of the six-cysteine motif. The synthetic peptides were resuspended in sterile deionized water at $20 \mathrm{mM}$ and stored at $-20^{\circ} \mathrm{C}$ prior to use. Chlorhexidine digluconate ( $\mathrm{CHX}$, Sigma Aldrich, St Louis, MO, USA) was used as a control. All subsequent experiments were performed in triplicate, in three independent assays.

\section{Cytotoxicity tests}

\section{Epithelial cell cultures}

The following cell lines were tested: immortalized human gingival epithelial cell line OBA-9 and skin epidermal HaCaT. The OBA-9 cells were cultured in K-SFM serumfree medium (Life Technologies), containing insulin, epidermal growth factor, fibroblast growth factor and $100 \mu \mathrm{g} \mathrm{ml}^{-1}$ of penicillin G/streptomycin. The HaCaT cells were cultured in Dulbecco's modified Eagle's medium DMEM (Gibco BRL, Carlsbad, CA, USA) plus 10\% fetal calf serum and $100 \mu \mathrm{g} \mathrm{ml}^{-1}$ of penicillin $\mathrm{G} /$ streptomycin. Both cell lines were grown until they reached subconfluent density at $37^{\circ} \mathrm{C}$ in $5 \% \mathrm{CO}_{2}$ (Bedran et al. 2014).

\section{Stimulation of epithelial cells by peptide fragments}

The epithelial cells were harvested following trypsin treatment (5 min) (TrypLETM Express; Life Technologies) at $37^{\circ} \mathrm{C}$. Proteases were then inactivated by adding $0.3 \mathrm{mg} \mathrm{ml}^{-1}$ of trypsin inhibitor and cells were harvested by centrifugation $(500 \times g$ for $5 \mathrm{~min}$ ), suspended in fresh medium, seeded in a 96-well microplate $\left(200 \mu \mathrm{l} \mathrm{well}{ }^{-1}\right.$, $1 \times 10^{6}$ cells $\mathrm{ml}^{-1}$ ) and incubated overnight at $37^{\circ} \mathrm{C}$ in a $5 \% \mathrm{CO}_{2}$ atmosphere to allow cell adhesion before stimulation. The cells were then stimulated with the peptide fragments (LL-37; D6-17; D1-23) and CHX at concentrations ranging from 1 to $0.001 \mathrm{mM}$ for $24 \mathrm{~h}$ at $37^{\circ} \mathrm{C}$ in $5 \% \mathrm{CO}_{2}$ (Bedran et al. 2014).

\section{Determination of cell viability}

A colorimetric MTT cell viability assay (Roche Diagnostics, Mannheim, Germany), using 3-[4,5-diethylthiazol-2-yl]-2,5-diphenyltetrazolium bromide as the substrate, was used to determine the effect of cationic peptide fragments and controls on cell viability. After exposure to the peptides and controls, the extracts were aspirated and replaced by $90 \mu \mathrm{l}$ of DMEM or K-SFM plus $10 \mu \mathrm{l}$ of MTT solution ( $5 \mathrm{mg} \mathrm{ml}^{-1}$ sterile PBS; Sigma Aldrich). Next, the culture medium with the MTT solution was aspirated and replaced with $100 \mu \mathrm{l}$ of acidified isopropanol solution. Two $50-\mu \mathrm{l}$ aliquots of each well were transferred to 96 -well plates. Cell viability was evaluated using spectrophotometry, being proportional to the absorbance measured at $\mathrm{OD}_{570 \mathrm{~nm}}$ with an ELISA microplate reader (Bio-Rad Laboratories, Hercules, CA, USA). The means were calculated for the groups and transformed into 
percentages, which represented the inhibitory effect of the mitochondrial activity of the cells by the peptides/CHX. The negative control (DMEM or K-SFM) was defined as having 100\% cell metabolism (Bedran et al. 2014).

\section{DAPI staining}

Apoptotic nuclear morphology was observed using 4,6-diamidino-2-phenylindole dihydrochoride (DAPI). $\mathrm{HaCaT}$ cells at a density of $2 \times 10^{5}$ cells well $^{-1}$ were placed on 24-well slides and treated with $0.1 \mathrm{mM}$ of each peptide fragment or CHX for $24 \mathrm{~h}$. Next, cells were washed with phosphate-buffered saline (PBS) and stained with DAPI solution, as described previously (Lai et al. 2011). After staining, the cells were examined and photographed using a fluorescence microscope (Leica, DM5500 B, Wetzer, Hesse, Germany).

\section{Antimicrobial tests}

\section{Bacterial conditions}

The following bacterial strains used in the present study were kindly provided by the Oswaldo Cruz Foundation (FIOCRUZ - Rio de Janeiro, São Paulo, Brazil): Streptococcus mutans (ATCC -25175), S. mitis (ATCC 4945), S. oralis (IAL -1676), S. sanguinis (ATCC 10557), S. salivarius (ATCC 7073), Lactobacillus acidophilus (ATCC 4356), L. paracasei (ATCC 335), L. rhamnosus (ATCC 9595), L. brevis (ATCC 367), L. fermentum (ATCC 9338) and Actinomyces israelii (ATCC 12102). Clinical S. mutans strains 1 and 2 (CS1 and CS2) were kindly provided by Renata Mattos-Graner and were previously isolated from ECC children and characterized as highly cariogenic (Mattos-Graner et al. 2004). The purity of the strains was confirmed by Gram stain. Microbial suspensions were prepared from a culture previously grown in mitis salivarius agar base (Difco Laboratories, Detroit, MI, USA) with $0.2 \mathrm{U} \mathrm{mg} \mathrm{ml}^{-1}$ bacitracin (Sigma-Aldrich) for S. mutans strains, mitis salivarius agar (Difco Laboratories) for the other Streptococcus strains (Difco Laboratories), Rogosa agar (Difco Laboratories) for Lactobacillus and brain heart infusion (BHI) agar (Difco Laboratories) for Actinomyces and incubated at $37^{\circ} \mathrm{C}$ for $24 \mathrm{~h}$ in $5 \% \mathrm{CO}_{2}$. Growth curve assays were performed for each bacterium in order to determine the OD at the mid-log phase with $\sim 5-10 \times 10^{8} \mathrm{CFU} \mathrm{m}{ }^{-1}$ to be used in subsequent experiments. The absorbance was measured using a microplate reader (Eon Microplate Spectrophotometer, Biotek Instruments, Winooski, VT, USA) to assess cell density.

\section{Determination of MIC and MBC}

The minimal inhibitory concentration (MIC) and minimal bactericidal concentration (MBC) were determined by the broth microdilution method, in 96-well microtiter plates, following the criteria previously described by the Clinical Laboratory Standards Institute M7-A9 (CLSI 2012) for bacteria. Bacterial cell cultures at the mid$\log$ phase were harvested by centrifugation (Hanil Combi centrifuge, 514R) for $10 \mathrm{~min}$, at 3,000 $\times g$, the supernatant was discarded and the pellet re-suspended in MuellerHinton broth (Difco Laboratories). The final concentration of bacterial suspension in the wells was $5-10 \times$ $10^{5} \mathrm{CFU} \mathrm{ml} \mathrm{m}^{-1}$. The fragments of cationic peptides were serially diluted in sterile deionized water at concentrations ranging from 1 to $0.001 \mathrm{mM}$. Next, a bacterial suspension was inoculated into each well. The plates were incubated at $37^{\circ} \mathrm{C}$ for $24 \mathrm{~h}$ in $5 \% \mathrm{CO}_{2}$. After this, $15 \mu \mathrm{l}$ of $0.01 \%$ resazurin stain (Sigma-Aldrich) was applied to each well and incubated for $4 \mathrm{~h}$ to determine cell viability (Hahnel et al. 2012). After that, wells corresponding to MIC and at least three previous wells were homogenized, serially diluted and plated on Mueller-Hinton agar to determine the $\mathrm{MBC}$. The plates were incubated at $37^{\circ} \mathrm{C}$ for $24 \mathrm{~h}$ in $5 \% \mathrm{CO}_{2}$. The number of colony forming units $\mathrm{ml}^{-1}$ $\left(\mathrm{CFU} \mathrm{m} \mathrm{m}^{-1}\right.$ ) of bacteria was determined. The MBC was considered when the peptides killed $99.9 \%$ of the tested bacterial culture. CHX and the culture medium were used as positive and negative controls, respectively.

\section{Determination of FIC}

The combined effects of peptide fragments were evaluated by the fractional inhibitory concentration (FIC) index, using the checkerboard assays as previously described (Tong et al. 2011). Briefly, the rows of a 96-well microplate contained the same concentrations of one of the peptide fragments (or two peptides, for triple combinations), diluted from 1 to $0.001 \mathrm{mM}$ along the $y$-axis. The column contained the same concentration of another peptide fragment, diluted from 1 to $0.001 \mathrm{mM}$ along the $x$-axis. After incubation for $24 \mathrm{~h}$ at $37^{\circ} \mathrm{C}$ in $5 \% \mathrm{CO}_{2}$, the plates were stained with resazurin for $4 \mathrm{~h}$. The FIC index was calculated according to the equation: FIC index = FIC A (MIC of antimicrobial A in combination/MIC of A alone) + FIC B (MIC of antimicrobial B in combination/MIC of $\mathrm{B}$ alone). The FIC values were interpreted as synergy if the values were $\leq 0.5$, no interaction if the values were between 0.5 and 4.0 and antagonism if the values were $>4.0$.

\section{Biofilm assays}

Biofilm assays were conducted with the peptide fragment, which demonstrated the greatest bactericidal effect against $S$. mutans strains (D1-23). This part of the study was reviewed and approved by the Animal and Human Research Ethics Committee of Araçatuba Dental School, Universidade Estadual Paulista, Brazil (Protocols: 198/2013 and \#CAAE 13079213.4.0000.5420). These 
assays were based on the study of Ccahuana-Vásquez and Cury (2010) with some modifications. Enamel blocks $(2 \mathrm{~mm} \times 2 \mathrm{~mm} \times 2 \mathrm{~mm})$ from bovine incisor teeth were cut and sequentially polished and selected through measurement of surface free energy (Drop Shape Analyzer DSA100, Krüss GmbH, Hamburg, Germany) (Brambilla et al. 2012). The mean \pm standard deviation (SD) of the free energy on the enamel blocks was $114 \pm 15 \mathrm{mM} \mathrm{m}^{-1}$ and they were carefully randomized and distributed into three groups ( $n=6)$ : a negative control (culture medium), D1-23 and CHX. The enamel blocks had been previously sterilized in water in glass tubes at $121^{\circ} \mathrm{C}$ for $30 \mathrm{~min}$ and their sterility was tested before use (Amaechi et al. 1998). The enamel blocks were fixed with double sided tape to the bottom of sterile polystyrene 96-well microplates, with a U-shaped base, and pretreated with $200 \mu \mathrm{l}$ of the stimulated saliva per well for $4 \mathrm{~h}$ at $37^{\circ} \mathrm{C}$ in $5 \% \mathrm{CO}_{2}$ (coating phase). The saliva was previously centrifuged at 3,000 $\times g$ for $10 \mathrm{~min}$ and the supernatant filtered through a $0.22-\mu \mathrm{m}$ membrane filter (Corning Inc., Corning, NY, USA). After the incubation time, the saliva was removed and $10 \mu \mathrm{l}$ of each microorganism suspension $\left(\sim 5-10 \times 10^{6} \mathrm{CFU} \mathrm{ml}^{-1}\right)$ was inoculated into each well containing $90 \mu \mathrm{l}$ of BHI broth supplemented with $1 \%$ sucrose. The plates were incubated at $37^{\circ}$ in a $5 \% \mathrm{CO}_{2}$ atmosphere. After $48 \mathrm{~h}$, the culture medium was removed and the wells were washed with sterile saline $(0.9 \% \mathrm{NaCl})$ for subsequent addition of $200 \mu \mathrm{l}$ of D1-23, CHX and water. The concentrations used for these assays were 2 and 10 times higher than the MBC concentration. The microplates were incubated under the same conditions for $24 \mathrm{~h}$. Specimens were carefully removed from the wells, washed in saline and individually transferred to microtubes containing $1 \mathrm{ml}$ of saline and sonicated at 7W for $30 \mathrm{~s}$ (Branson, Sonifier 50, Danbury, CT, USA) to detach cells from the biofilm formed on the enamel specimens (Ccahuana-Vásquez \& Cury 2010). Aliquots of the suspension were diluted and inoculated in BHI agar. The plates were incubated for $48 \mathrm{~h}$ at $37^{\circ} \mathrm{C}$, with $5 \% \mathrm{CO}_{2}$. After this period, bacterial colonies were counted and expressed in CFU ml ${ }^{-1}$.

\section{Confocal laser scanning microscopy (CLSM)}

Biofilm assays for CLSM analysis were conducted with S. mutans ATCC testing the peptide that showed the best antimicrobial activity on MIC/MLC assays. Enamel blocks ( $n=6$ ) measuring $3 \mathrm{~mm} \times 3 \mathrm{~mm} \times 0.5 \mathrm{~mm}$ were inserted in wells, as described above and the biofilm formed over $48 \mathrm{~h}$ was exposed to peptide (D1-23) or CHX at 10× the MBC concentration for $24 \mathrm{~h}$. After this period, enamel blocks were washed once with sterile deionized water and stained with $100 \mu \mathrm{l}$ of fluorescent Live/Dead BacLight Bacterial Viability stain (L13152, Molecular Probes, Eugene, OR, USA) containing SYTO 9 and propidium iodide, according to the manufacturer's instructions. The excitation/emission wavelengths were $480 / 500 \mathrm{~nm}$ for SYTO 9 and 490/635 nm for propidium iodide. Two additional uninfected specimens were stained using the same proto$\mathrm{col}$ and used as negative controls. Fluorescence from the stained cells was viewed by CLSM (Leica TCS SP5, Leica Microsystems, Lincolnshire, IL, USA), using a $63 \times$ oil immersion lens. CLSM images were acquired using software (LAS AF Leica Microsystems) at a resolution of 1,024 by 1,024 pixels. Ten-micrometer-deep scans $(0.2-\mu \mathrm{m}$ step size) were obtained from two randomly selected places with the CLSM. In order to analyze the Live/Dead cells ratios on the enamel slices, all scans were reconstructed in a 3-D model by the same software. The quantification of red fluorescence ratio in relation to green-and-red fluorescence and biofilm thickness were determined by software ImageJ 1.48 (NIH, Bethesda, MA, USA) (Lee et al. 2013).

\section{Statistical analysis}

Data from the cytotoxicity assays were analyzed using the ANOVA/Tukey tests in order to compare the effects of the peptide fragments on epithelial cells, considering each concentration separately. Box-whisker plots were drawn to represent the distribution of non-parametric data obtained in the biofilm assays and Mann-Whitney tests were applied to compare D1-23 with CHX for each S. mutans strain. CLSM data (quantification of dead cells in relation to the total cells and biofilm thickness) were converted to mean/SD and analyzed using ANOVA and Tukey tests $(p<0.05)$. SPSS 19.0 software (SPSS Inc., Chicago, IL, USA) was used to run the statistical analysis.

\section{Results}

\section{Cytotoxicity tests}

Figures 1 and 2 present the percentage metabolism of $\mathrm{HaCat}$ and OBA-9, respectively. After exposure for $24 \mathrm{~h}$, D6-17 did not affect the cell metabolism of either epithelial line at the concentrations tested. D1-23 showed toxicity at concentrations $>0.2 \mathrm{mM}$ for both epithelial cells. LL-37 and CHX were the most cytotoxic peptides, demonstrating toxicity at concentrations $>0.02 \mathrm{mM}$ for both cells. Figure 3 shows representative fluorescence microscope images of HaCaT cells exposed to peptide fragments at $0.1 \mathrm{mM}$. At higher intensity, DAPI-stained cells and the presence of fragmented nuclei, as a consequent of nuclear condensation and chromatin shrinkage, were observed for the LL-37 group and cells undergoing apoptosis in the CHX group. Cells treated with D1-23 and D6-17 had a similar morphology to the control group (culture medium). 


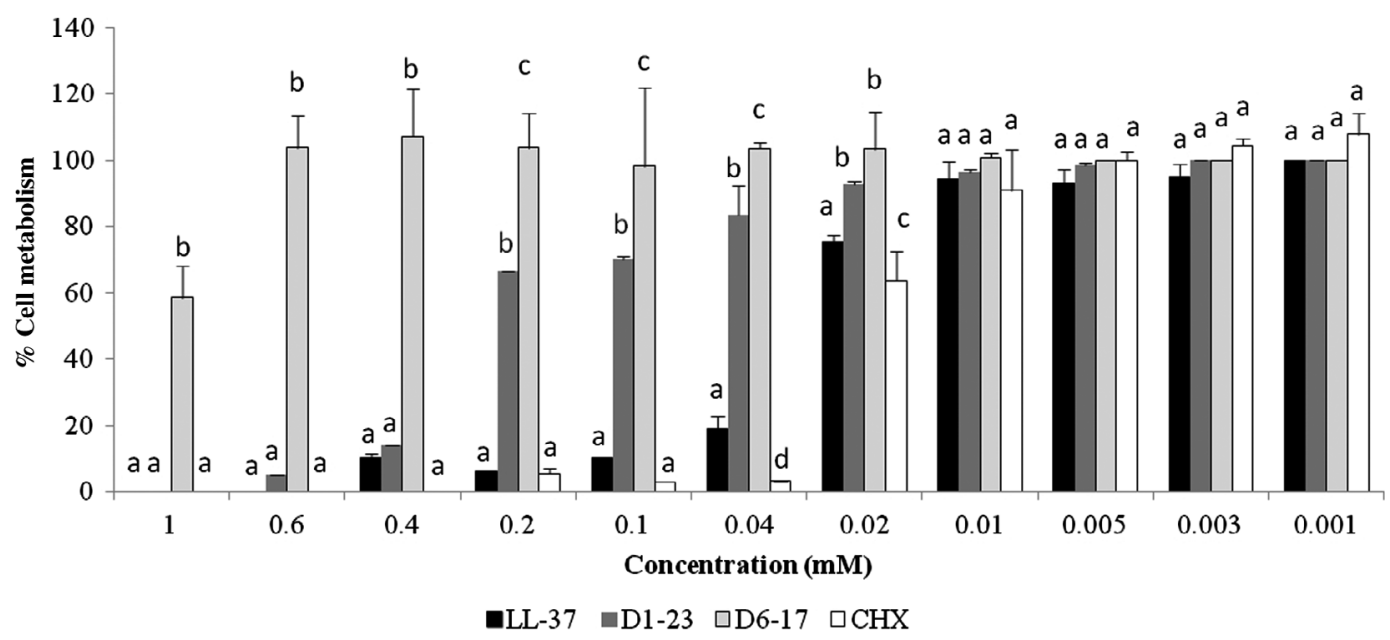

Figure 1. Mean (bars = SD) of the percentage of HaCat cell metabolism (MTT assay) after exposure to CHX and peptide fragments. Different lower case letters show statistical differences among the groups, considering each concentration separately, according to ANOVA and Tukey tests.

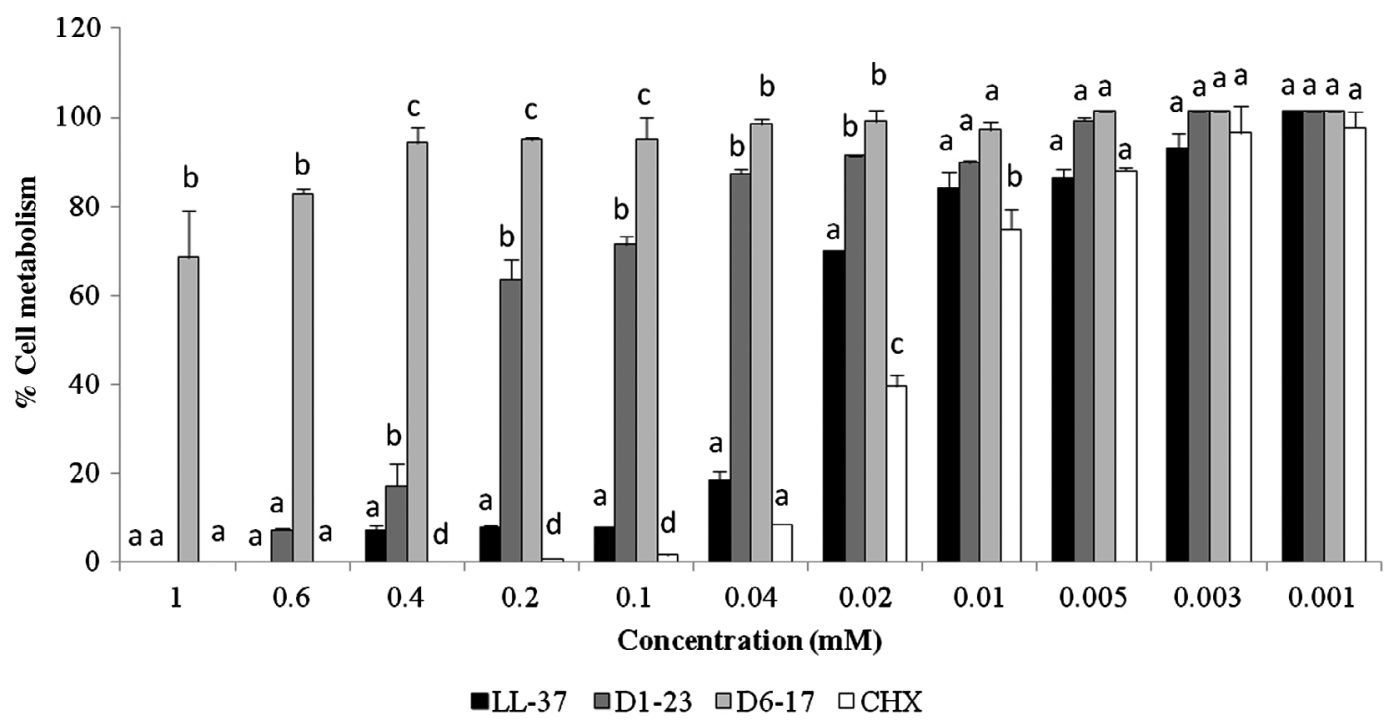

Figure 2. Mean (bars = SD) of the percentage of OBA-9 cell metabolism (MTT assay) after exposure to CHX and peptide fragments. Different lower case letters show statistical differences among the groups, considering each concentration separately, according to ANOVA and Tukey tests.

\section{Antimicrobial activity (planktonic condition)}

Table 1 shows the MIC and MBC values obtained for the cationic peptide fragments. CHX demonstrated the best antibacterial effect against all the bacteria tested. Among the peptide fragments, D1-23 demonstrated the best bactericidal activity against $S$. mutans strains, $S$. mitis and S. salivarius with MIC values ranging from 0.003 to $0.1 \mathrm{mM}$ and $\mathrm{MBC}$ ranging from 0.005 to $0.2 \mathrm{mM}$. D1-23 did not have an effect on S. oralis or S. sanguinis, but it showed better results against Lactobacillus spp. and Actinomyces israelii (MIC/MBC range: 0.003-0.4 mM). LL-37 demonstrated a superior effect against the
Lactobacillus and Actinomyces species tested; however, its efficacy against Streptococcus spp. was less than D1-23. D6-17 showed bactericidal activity only against $S$. mutans strains, L. brevis and L. fermentum. Table 2 presents the FIC values for peptides combinations and no synergic effect was observed against $S$. mutans.

\section{Effect against S. mutans biofilm}

Box-whisker plots showed a reduction in the percentage of $S$. mutans after exposure for $24 \mathrm{~h}$ to D1-23 and CHX. Both agents improved their activity against biofilm of all S. mutans strains with an increase in concentration (2 to 

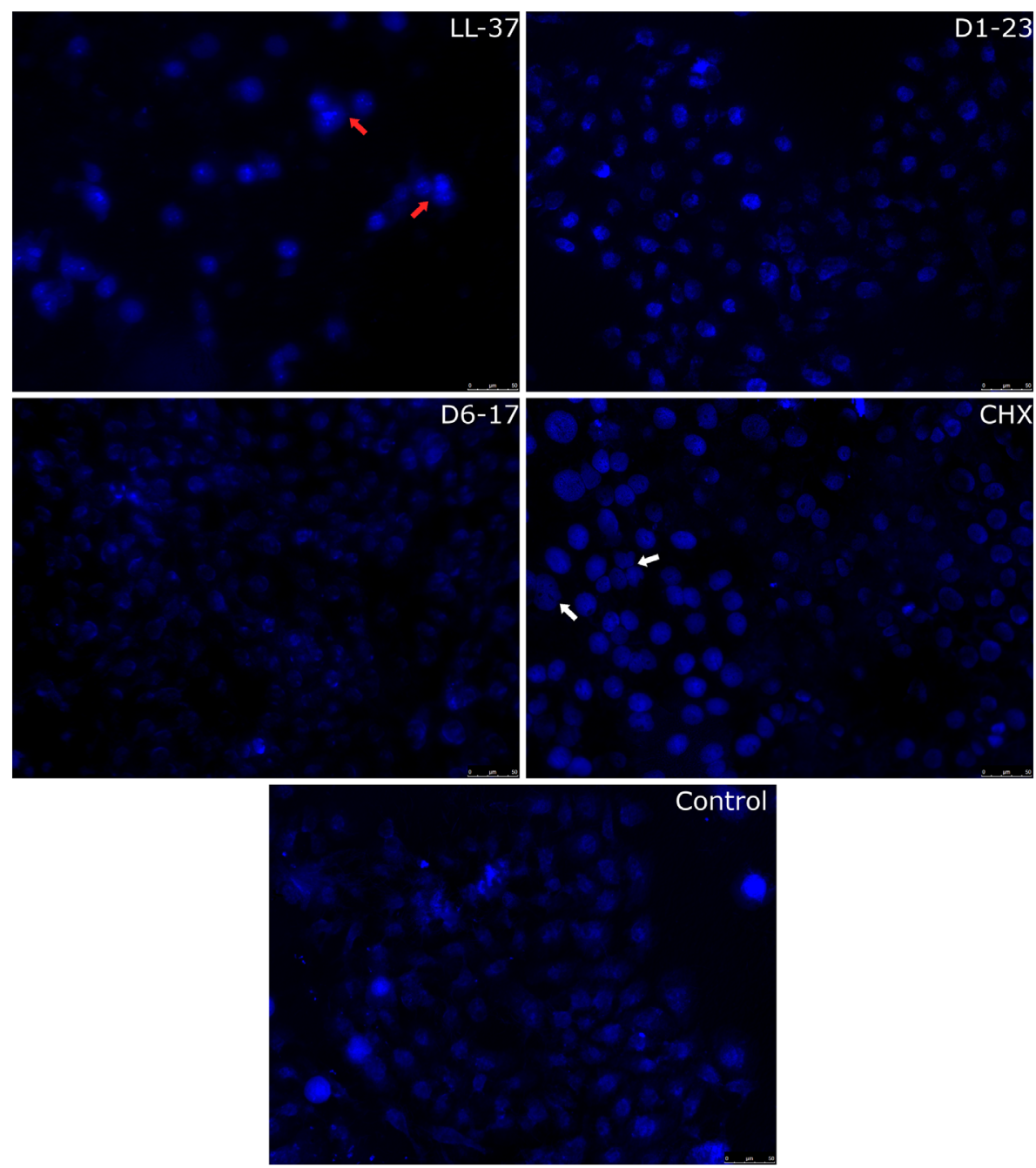

Figure 3. Fluorescence microscope images $(\times 200)$ of HaCaT cells treated with peptide fragments (LL-37, D1-23 and D6-17) and CHX for $24 \mathrm{~h}$. Red arrows show a higher intensity of DAPI-staining cells and the presence of fragmented nuclei observed for the LL-37 group. White arrows show cells with apoptosis in the CHX group. Control = the culture medium (DMEM).

Table 1. The MIC (and $\mathrm{MBC})^{\dagger}$ values obtained for the cationic peptide fragments against oral bacteria.

\begin{tabular}{|c|c|c|c|c|}
\hline & LL-37 mM & D1-23 mM & D6-17 mM & $\mathrm{CHX} \mathrm{mM}$ \\
\hline S. mutans (ATCC) & $0.1(0.2)$ & $0.01(0.02)$ & $0.1(0.2)$ & $0.001(0.003)$ \\
\hline S. $m$ clinical strain 1 (CS1) & $0.2(0.2)$ & $0.003(0.005)$ & $0.4(0.4)$ & $0.001(0.001)$ \\
\hline S. $m$ clinical strain 2 (CS2) & $0.1(0.1)$ & $0.01(0.01)$ & $0.1(0.2)$ & $0.001(0.003)$ \\
\hline S. salivarius & $0.005(0.01)$ & $0.005(0.01)$ & $0.4(0.6)$ & $0.001(0.005)$ \\
\hline S. mitis & $0.01(0.02)$ & $0.1(0.2)$ & $0.6(>1)$ & $0.005(0.005)$ \\
\hline S. oralis & $0.2(0.4)$ & $>1(>1)$ & $1(>1)$ & $0.02(0.02)$ \\
\hline S. sanguinis & $>1(>1)$ & $>1(>1)$ & $>1(>1)$ & $0.01(0.02)$ \\
\hline L. acidophilus & $0.01(0.01)$ & $0.4(0.4)$ & $>1(>1)$ & $0.003(0.02)$ \\
\hline L. casei & $0.02(0.2)$ & $0.4(>1)$ & $>1(>1)$ & $0.003(0.02)$ \\
\hline L. rhamnosus & $0.01(0.01)$ & $0.4(0.4)$ & $>1(>1)$ & $0.003(0.003)$ \\
\hline L. brevis & $0.001(0.001)$ & $0.003(0.003)$ & $0.02(0.02)$ & $0.001(0.001)$ \\
\hline L. fermentum & $0.001(0.003)$ & $0.005(0.02)$ & $0.4(0.6)$ & $0.001(0.005)$ \\
\hline Actinomyces israelii & $0.005(0.04)$ & $0.02(0.2)$ & $0.4(>1)$ & $0.005(0.02)$ \\
\hline
\end{tabular}

${ }^{\dagger} \mathrm{MIC}$ - Minimum inhibitory concentration; MBC - minimal bactericidal concentration.

$10 \times \mathrm{MBC})$. At $2 \times \mathrm{MBC}, \mathrm{CHX}$ presented a similar effect for all the strains tested. D1-23 at $2 \times \mathrm{MBC}$ was superior to CHX only against $S$. mutans ATCC. This strain was more sensitive to D1-23 than the other S. mutans strains, showing the highest bacterial reduction at $10 \times \mathrm{MBC}$. D1-23 demonstrated a better effect against $S$. mutans biofilms than $\mathrm{CHX}$ at $10 \times \mathrm{MBC}$, except for S. mutans CS1 (Figure 4). Representative images obtained from CLSM 
Table 2. Values of FIC obtained by combinations of fragments of cationic peptides against S. mutans (ATCC 25175).

\begin{tabular}{lcc}
\hline & FIC $^{*}$ & Effect \\
\hline Double combination & & \\
D6-17+D1-23 & 2.4 & No interaction \\
D6-17+LL37 & 2.4 & No interaction \\
D1-23+LL-37 & 2.1 & No interaction \\
Triple combination & & \\
D6-17+D1-23+LL-37 & 2.5 & No interaction \\
\hline
\end{tabular}

${ }^{*} \mathrm{FIC}$ index $=\mathrm{FIC} \mathrm{A}+\mathrm{FIC} B=(\mathrm{MIC}$ of antimicrobial $\mathrm{A}$ in combination $/ \mathrm{MIC}$ of $\mathrm{A}$ alone) + (MIC of antimicrobial $B$ in combination/MIC of $B$ alone). Synergism was defined as an FIC index \# 0.5; no interaction as an FIC index of 0.5-4.0 and antagonism as an FIC index > 4.0.

analysis from $S$. mutans biofilm on enamel blocks are shown in Figure 5A. The D1-23 and CHX images show more dead cells (red points) when compared to the control (culture medium) images which showed mostly live cells (green points). D1-23 demonstrated greater activity against $S$. mutans biofilms than CHX and the control groups, with an average of $71 \%$ red cells, indicating cell death (Figure 5B). The biofilm thickness decreased in the D1-23 group compared to the CHX and control groups, as shown in Figure 6A and B.

\section{Discussion}

The aim of this study was to identify smaller peptide sequences with the same or better antimicrobial activity than the original oral cationic peptides, with no cytotoxicity, thereby reducing costs and difficulties with synthesis and as well as other limitations. In the present study, three cationic peptide-derived fragments were evaluated: D6-17, D1-23 and LL37 with charge of $+5,+7$ and +6 , pH.7.0, respectively (Dürr et al. 2006; Reynolds et al. 2010). Reynolds et al. (2010) synthesized several overlapping fragments of Defb14 (mouse ortholog of human $\beta$-defensin 3) and Defb14-1C $C^{\mathrm{v}}$ (peptide with cysteines replaced with alanines except $\mathrm{Cys}_{40}$, which resides at position $\mathrm{V}$ of the six-cysteine motif) and determined planktonic antimicrobial activity. Defb14-1C $\mathrm{C}^{\mathrm{v}}$ (D1-23) and Defb14$1 \mathrm{C}^{\mathrm{v}}$ (D6-17) had the best MBCs against Gram-positive and Gram-negative bacterial strains. LL-37 was also chosen for this study based on its antimicrobial activity reported in previous studies (Gordon et al. 2005; Ouhara et al. 2005).

One limitation to the use of peptides as future drugs is their toxicity to the host cell at therapeutic concentrations. In the present study, D6-17 did not affect cell metabolism and D1-23 demonstrated good results up to $0.2 \mathrm{mM}$ for both cell lines. It is well known that cationic peptides not only interact with microorganisms, but also with eukaryotic cells, causing toxicity. Hydrophobic interactions occur between anionic phosphatidylglycerol from bacterial cell membranes and with zwitterionic phosphatidylcholine and phosphatidylethanolamine from mammalian cells (Yeaman \& Yount 2003). The cytotoxicity of hBD-3 fragments is related to hydrophobicity, which decreases as the length of the peptide decreases (Reynolds et al. 2010). D1-23 was more cytotoxic than D6-17 as it possesses a longer $\mathrm{N}$-terminal length and consequently higher hydrophobicity (Ji et al. 2007). The present results are in

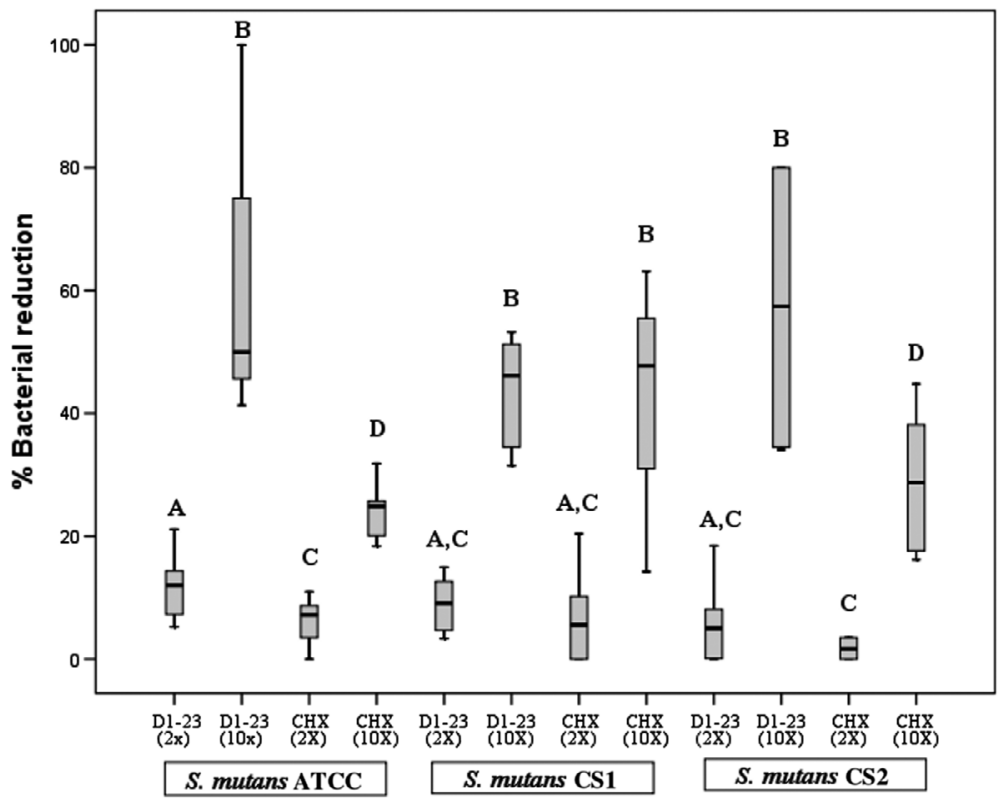

Figure 4. Box-whisker plots of the activity of D1-23 $(2 \times \mathrm{MBC}$ and $10 \times \mathrm{MBC})$ and $\mathrm{CHX}(2 \times \mathrm{MBC}$ and $10 \times \mathrm{MBC})$ against biofilms of S. mutans ATCC and clinical strains (CS1 and CS2). Different upper case letters show statistical differences among the groups, considering each strain separately, according to Mann-Whitney tests. Bars indicate minimum and maximum values. Boxes indicate lower and upper quartiles. The line in the middle of the boxes is the median. 

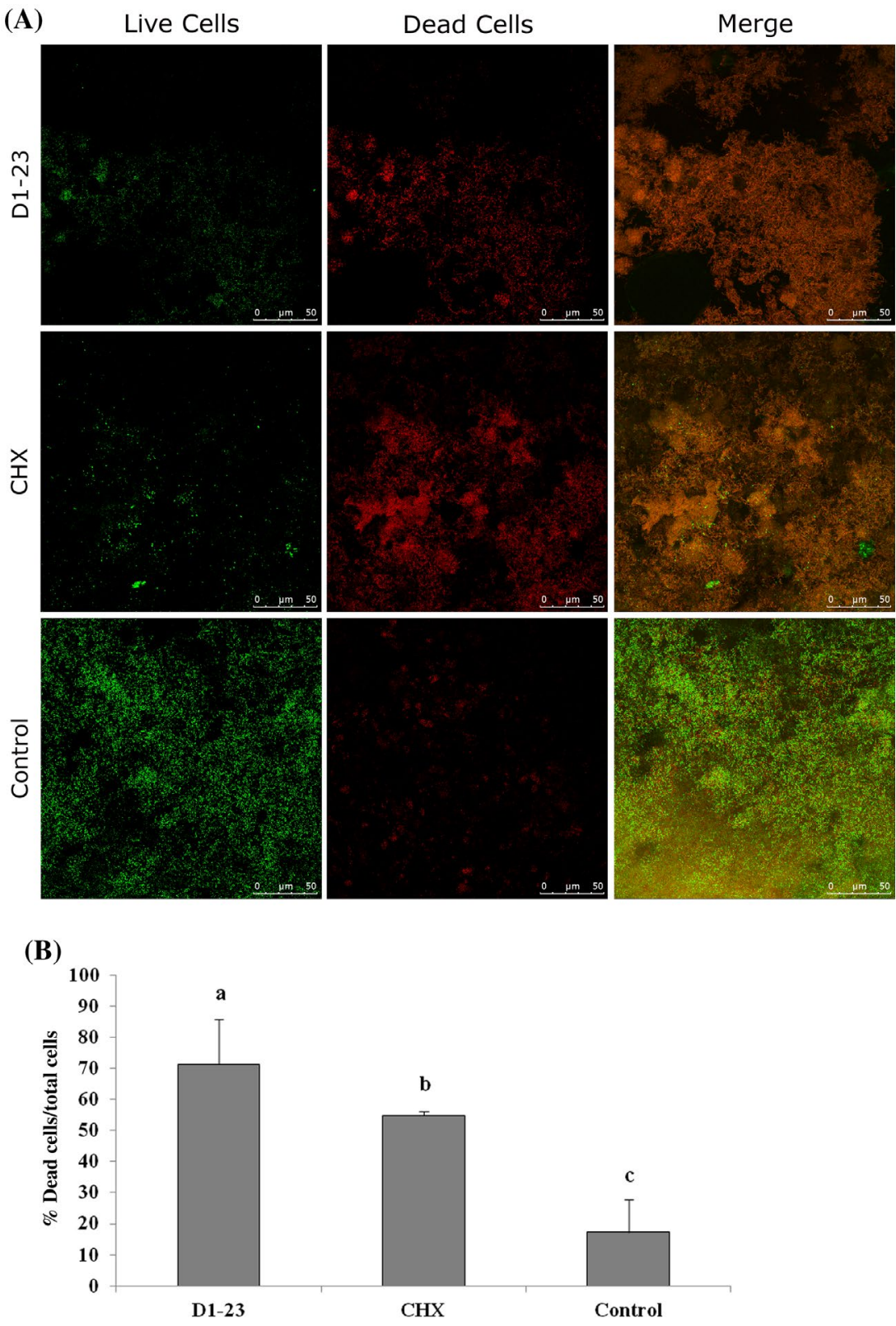

Figure 5. CLSM images of S. mutans biofilms on enamel blocks after exposure to D1-23 and CHX. (A) Representative images ( $\times 63$ immersion) of dead cells and live cells and merge images of S. mutans biofilms. D1-23 and CHX showed higher quantities of dead cells (red points) when compared to the control (no treatment) which presented a strong predominance of live cells (green points). (B) Means (bars - SDs) of the percentage of dead cells obtained after CLSM analysis of S. mutans biofilm. Different lower case letters show statistical differences among the groups, according to ANOVA and Tukey tests $(p<0.05)$.

agreement with those of Klüver et al. (2005), who tested the cytotoxicity of hBD-3 peptides with three disulfide bonds and the analogs containing alanine and tryptophan for the cysteine residues. They showed that replacement of cysteine residues with alanine caused a reduction in the overall hydrophobicity, making the analogs less cytotoxic. Alanine has one methyl group in its side chain while cysteine has a sulfhydryl. D1-23 and D6-17 are alanine-substituted hBD-3 variants demonstrating an advantage in relation to disulfide bonds in peptides or analogs containing tryptophan, which exhibit a markedly higher potency in reducing human monocytic cell viability (Yeaman \& Yount 2003). In contrast, Liu et al. (2008) also tested the cytotoxicity of linear analogs of hBD3 and, regardless of their hydrophobicity, they showed reduced epithelial toxicity when compared with wild-type hBD3 in the concentration range of $6.25-200 \mu \mathrm{g} \mathrm{ml}^{-1}$.

In the present study, LL-37 was the most toxic peptide fragment to epithelial cells, with a reduction in cytotoxicity at concentrations $<0.02 \mathrm{mM}$. DAPI fluorescence analysis confirmed the toxic effect of LL-37 at $1 \mathrm{mM}$ causing fragmentation of cell nuclei. The effect of LL-37 on 


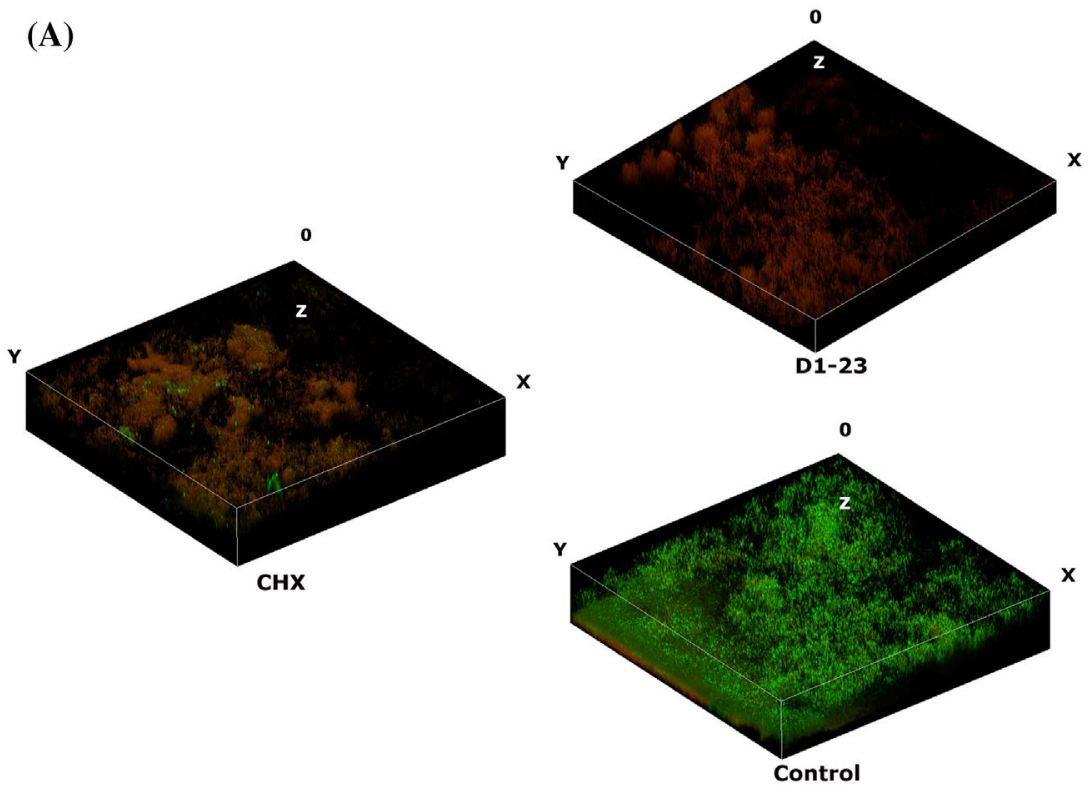

(B)

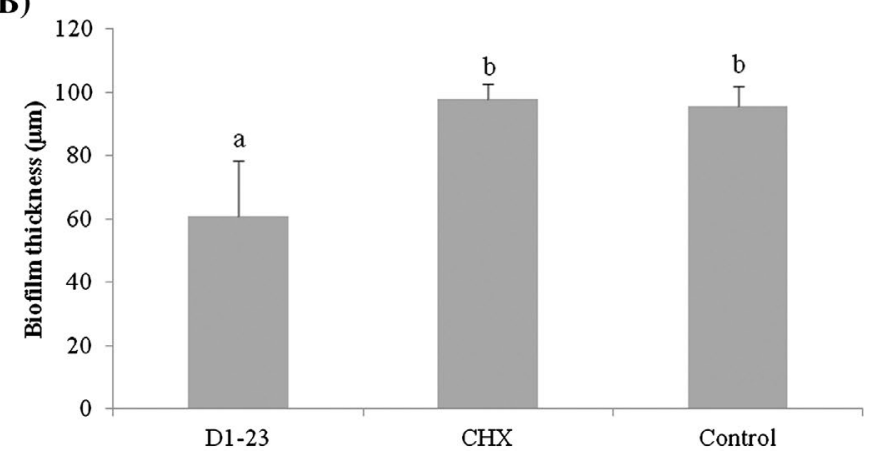

Figure 6. Biofilm thickness. (A) Representative 3-D CLSM images of S. mutans biofilms after exposure to D1-23 and CHX for 24 h. (B) Means (bars - SDs) of biofilm thickness obtained after CLSM analysis of S. mutans biofilm. Different lower case letters show statistical differences among the groups, according to ANOVA and Tukey tests $(p<0.05)$. Control $=$ no treatment.

mammalian cells, but not epithelial cells, was first studied by Johansson et al. (1998) who observed cytotoxicity at 13-25 $\mu \mathrm{M}$, which gradually increased at higher concentrations. In a culture of gingival epithelial cells (HGEC), similar to OBA-9 lines, obtained from gingival tissue overlying impacted third molars of patients, doses of LL-37 up to $6 \mu \mathrm{M}$ did not significantly decrease the percentage survival of HGEC (Montreekachon et al. 2014). In the human body, a high concentration of LL-37 is controlled by its binding to plasma proteins, such as apolipoprotein A-I, reducing both cytotoxicity and antimicrobial activity (Ciornei et al. 2005). Studies have focused on more active fragments or analogs of LL-37 with a less cytotoxic effect (Johansson et al. 1998; Ciornei et al. 2005). All peptide fragments were less cytotoxic than CHX solution. Images of DAPI stained samples showed apoptosis in epithelial cells treated with CHX, as observed in different types of cells in other studies (Giannelli et al. 2008; Rocha et al. 2014). CHX has been implicated as an apoptosis-promoting agent because it induces disturbances of mitochondrial function, and increases in intracellular $\mathrm{Ca}^{+2}$ and oxidative stress (Giannelli et al. 2008).

For the present study, some early colonizers (S. sanguinis, S. mitis, S. oralis, and Actinomyces spp.) and late colonizers (S. mutans, S. sobrinus, and Lactobacillus spp.) related to dental biofilm formation were chosen to test the antimicrobial activity of cationic peptide fragments. Among the fragments of peptides, D1-23 demonstrated the best bactericidal activity against $S$. mutans strains, $S$. mitis and S. salivarius and good results against Lactobacillus spp. and Actinomyces israelii. Reynolds et al. (2010) discovered that the 23-amino-acid N-terminal half of Defb14-1CV is a potent antimicrobial region while the $\mathrm{C}$-terminal half is not. The regions containing the amino acids $1-10$ and 6-17 demonstrated a potent bactericidal effect; however, D6-17 showed a strong inhibitory action against Gramnegative strains (Reynolds et al. 2010). In the present study, D1-23 was more effective than D6-17 against cariogenic 
bacteria, confirming the better efficacy of D1-23 on Grampositive bacteria compared to other Defb14 peptide fragments (Reynolds et al. 2010). Biofilm reduction superior to that of CHX solution was observed for D1-23 at $10 \times$ MBC against $S$. mutans strains, except for $S$. mutans CS1. Confocal analysis also showed a greater effect against S. mutans biofilms and thinner biofilms for D1-23 treatment when compared to CHX and the control groups. The effect of antimicrobial agents on biofilms depends on several factors, such as depletion of the treatment in the fluid phase, penetration of the antibiotics and the physiology (stages of growth) of the biofilms. The first and last factors are probably not general causes of biofilm tolerance in in vitro models. However, penetration times could interfere in the ability of antibiotics to reduce biofilm biomass. Conversely, penetration times do not increase with the molecular weight of the antimicrobial agent. Even large antibiotics and antimicrobial peptides can penetrate a biofilm within a few minutes. Some examples of large agents that penetrate rapidly within biofilms are vancomycin (0.5 min), daptomycin (1.5 min), and nisin (4-10 min) (Stewart et al. 2015).

There are no previous studies evaluating the effect of D1-23 and D6-17 against biofilms. However, the original human form, hBD-3, exhibited more antibacterial activity against mature multispecies biofilms of $S$. mutans, A. naeslundii, L. salivarius and E. faecalis than CHX (Lee et al. 2013). Both the structure and the sequence are important for the antimicrobial activity of these $\beta$-defensin derivatives (Reynolds et al. 2010). The mechanism of action of defensins is associated with peptide binding to the bacterial cell membrane. Ionic interaction of cationic defensins with negatively charged phospholipids causes permeabilization and cell lysis (Abiko et al. 2003; Ganz 2003). Sahl et al. (2005) found that membrane depolarization contributes to rapid killing of a significant number of bacterial cells within a culture. However, subpopulations appear to survive and grow or are killed by other activities of the peptides, such as the activation of cell wall lytic enzymes.

Another important cationic peptide tested in the present study was LL-37. This peptide demonstrated a superior effect against the Lactobacillus and Actinomyces species tested; however, its action on Streptococcus spp. was lower when compared to D1-23. LL-37 acts on the outer membrane of bacterial cells binding with positively charged amino acids in contact with the head groups of the phospholipids. The accumulation of peptides causes small toroidal pores that lead to severe leakage. Additionally, the inner membrane is covered in a carpet-like manner, allowing intracellular targets such as DNA binding with LL-37. Electrostatic interaction with protein complexes responsible for electron transport may also occur with
LL-37, generating ATP, which could lead to the disruption of membrane homeostasis (reviewed by Vandamme et al 2012). Ouhara et al. (2005) evaluated the inhibitory effect of LL-37 on the cariogenic bacteria S. mutans, S. sobrinus, S. salivarius, S. sanguinis, $S$. mitis and L. casei and found MICs ranging from $25-50 \mu \mathrm{g} \mathrm{ml}^{-1}(\sim 0.01 \mathrm{mM})$, lower than obtained in the present study. In contrast to the present study, the authors found a superior effect of LL-37 against streptococci when compared to $L$. casei. In the present study, synergism was not observed among peptide fragments. LL-37 and hBD-3 had a synergic effect on killing S. aureus at $\mathrm{pH} 8.0$ and 7.4 that was eliminated at pH 6.8 (Abou Alaiwa et al. 2014). S. mutans is considered highly acidogenic (van Houte et al. 1991; Mattos-Graner et al. 2014) and the $\mathrm{pH}$ of the culture medium could have interfered in the synergism of the peptides.

There is a demand for novel antimicrobials due to the current trend of loss of potency of commonly used antibiotics. Peptides could be an alternative to conventional antimicrobials because they selectively target prokaryotes and minimally trigger the emergence of microbial resistance. However, native peptides tend to be easily degraded, are expensive to produce and have been shown to be toxic in their active forms (Abiko et al. 2003; Wiesner \& Vilcinskas 2010; Batoni et al. 2011). The design of synthetic fragments of peptides with a broad spectrum of action against bacterial pathogens, low toxicity to the host and low production costs could be useful for oral application as a method for caries prevention.

\section{Conclusion}

Of the limited number of peptide fragments tested in the present study, D1-23 showed good efficacy against cariogenic bacteria under planktonic and biofilm conditions and a low toxicity to epithelial cells.

\section{Acknowledgements}

The authors would like to thank Prof. Dr Débora Simões de Almeida Colombari and Rafaela Moreira Barbosa from the Araraquara Dental School - UNESP, for their help with the DAPI analysis and the use of the fluorescence microscope.

\section{Disclosure statement}

No potential conflict of interest was reported by the authors.

\section{Funding}

This work was supported by the São Paulo Research Foundation (FAPESP), Brazil [grant number 2012/192355], [grant number 2013/12285-0]. 


\section{References}

Abiko Y, Nishimura M, Kaku T. 2003. Defensins in saliva and the salivary glands. Med Electron Microsc. 36:247-252. doi:http://dx.doi.org/10.1007/s00795-003-0225-0

Abou Alaiwa MH, Reznikov LR, Gansemer ND, Sheets KA, Horswill AR, Stoltz DA, Zabner J, Welsh MJ. 2014. $\mathrm{pH}$ modulates the activity and synergism of the airway surface liquid antimicrobials $\beta$-defensin-3 and LL-37. Proc Natl Acad Sci USA. 111:18703-18708. doi:http://dx.doi. org/10.1073/pnas.1422091112

Amaechi BT, Higham SM, Edgar WM. 1998. Efficacy of sterilisation methods and their effect on enamel demineralisation. Caries Res. 32:441-446. doi:http://dx.doi. org/10.1159/000016485

Batoni G, Maisetta G, Brancatisano FL, Esin S, Campa M. 2011. Use of antimicrobial peptides against microbial biofilms: advantages and limits. Curr Med Chem. 18:256279. doi:http://dx.doi.org/10.2174/092986711794088399

Bedran TB, Mayer MP, Spolidorio DP, Grenier D. 2014. Synergistic anti-inflammatory activity of the antimicrobial peptides human beta-defensin-3 (hBD-3) and cathelicidin (LL-37) in a three-dimensional co-culture model of gingival epithelial cells and fibroblasts. PLOS ONE. 9:e106766. doi:http://dx.doi.org/10.1371/journal.pone.0106766

Benergossi J, Calixto G, Fonseca-Santos B, Aida KL, de Cássia Negrini TC, Duque C, Gremião MP, Chorilli M. 2015. Highlights in peptide nanoparticle carriers intended to oral diseases. Curr Top Med Chem. 15:345-355. doi:http:// dx.doi.org/10.2174/1568026615666150108125040

Brambilla E, Ionescu A, Gagliani M, Cochis A, Arciola CR, Rimondini L. 2012. Biofilm formation on composite resins for dental restorations: an in situ study on the effect of chlorhexidine mouthrinses. Int J Artif Organs. 35:792-799. doi:http://dx.doi.org/10.5301/ijao.5000165

Ccahuana-Vásquez RA, Cury JA. 2010. S. mutans biofilm model to evaluate antimicrobial substances and enamel demineralization. Braz Oral Res. 24:135-141. doi:http:// dx.doi.org/10.1590/S1806-83242010000200002

Ciornei CD, Sigurdardóttir T, Schmidtchen A, Bodelsson M. 2005. Antimicrobial and chemoattractant activity, lipopolysaccharide neutralization, cytotoxicity, and inhibition by serum of analogs of human cathelicidin LL-37. Antimicrob Agents Chemother. 49:2845-2850. doi:http:// dx.doi.org/10.1128/AAC.49.7.2845-2850.2005

CLSI - Clinical and Laboratory Standards Institute. 2012. Methods for dilution antimicrobial susceptibility tests for bacteria that grow aerobically; approved standard. 9th ed. Wayne, PA, CLSI Document, M7-A9.

da Silva BR, de Freitas VA, Carneiro VA, Arruda FV, Lorenzón EN, de Aguiar AS, Cilli EM, Cavada BS, Teixeira EH. 2013. Antimicrobial activity of the synthetic peptide Lys-a1 against oral streptococci. Peptides. 42:78-83. doi:http:// dx.doi.org/10.1016/j.peptides.2012.12.001

Dürr UH, Sudheendra US, Ramamoorthy A. 2006. LL-37, the only human member of the cathelicidin family of antimicrobial peptides. Biochim Biophys Acta. 1758:14081425.

Dye BA, Hsu KL, Afful J. 2015. Prevalence and measurement of dental caries in young children. Pediatr Dent. 37:200-216.

Ganz T. 2003. Defensins: antimicrobial peptides of innate immunity. Nat Rev Immunol. 3:710-720. doi:http://dx.doi. org/10.1038/nri1180
Giannelli M, Chellini F, Margheri M, Tonelli P, Tani A. 2008. Effect of chlorhexidine digluconate on different cell types: a molecular and ultrastructural investigation. Toxicol In Vitro. 22:308-317. doi:http://dx.doi.org/10.1016/j.tiv.2007.09.012

Gordon YJ, Romanowski EG, McDermott AM. 2005. A review of antimicrobial peptides and their therapeutic potential as anti-infective drugs. Curr Eye Res. 30:505-515. doi:http:// dx.doi.org/10.1080/02713680590968637

Hahnel S, Mühlbauer G, Hoffmann J, Ionescu A, Bürgers R, Rosentritt M, Handel G, Häberlein I. 2012. Streptococcus mutans and Streptococcus sobrinus biofilm formation and metabolic activity on dental materials. Acta Odontol Scand. 70:114-121. doi:http://dx.doi.org/10.3109/00016357.2011.6 00703

Horowitz HS. 1998. Research issues in early childhood caries. Commun Dent Oral Epidemiol. 26:67-81. doi:http://dx.doi. org/10.1111/j.1600-0528.1998.tb02096.x

Ji S, Hyun J, Park E, Lee BL, Kim KK, Choi Y. 2007. Susceptibility of various oral bacteria to antimicrobial peptides and to phagocytosis by neutrophils. J Periodontal Res. 42:410-419. doi:http://dx.doi.org/10.1111/j.1600-0765.2006.00962.x

Johansson J, Gudmundsson GH, Rottenberg ME, Berndt KD, Agerberth B. 1998. Conformation-dependent antibacterial activity of the naturally occurring human peptide LL-37. J Biol Chem. 273:3718-3724. doi:http://dx.doi.org/10.1074/ jbc.273.6.3718

Klüver E, Schulz-Maronde S, Scheid S, Meyer B, Forssmann WG, Adermann K. 2005. Structure-activity relation of human beta-defensin 3: influence of disulfide bonds and cysteine substitution on antimicrobial activity and cytotoxicity. Biochemistry. 44:9804-9816. doi:http://dx.doi. org/10.1021/bi050272k

Lai WW, Hsiao YP, Chung JG, Wei YH, Cheng YW, Yang JH. 2011. Synergistic phototoxic effects of glycolic acid in a human keratinocyte cell line (HaCaT). J Dermatol Sci. 64:191-198. doi:http://dx.doi.org/10.1016/j.jdermsci.2011.09.001

Lee JK, Chang SW, Perinpanayagam H, Lim SM, Park YJ, Han SH, Baek SH, Zhu Q, Bae KS, Kum KY. 2013. Antibacterial efficacy of a human $\beta$-Defensin-3 peptide on multispecies biofilms. J Endod. 39:1625-1629. doi:http://dx.doi.org/ 10.1016/j.joen.2013.07.035

Liu S, Zhou L, Li J, Suresh A, Verma C, Foo YH, Yap EP, Tan DT, Beuerman RW. 2008. Linear analogues of human beta-defensin 3: concepts for design of antimicrobial peptides with reduced cytotoxicity to mammalian cells. Chembiochem. 9:964-973. doi:http://dx.doi.org/10.1002/ cbic. 200700560

Losso EM, Tavares MC, Silva JY, Urban CA. 2009. Severe early childhood caries: an integral approach. J Pediatr. 85:295300. doi:http://dx.doi.org/10.1186/s12903-015-0093-8

Mattos-Graner RO, Corrêa MSNP, Latorre MRO, Peres RCR, Mayer MPA. 2001. Mutans streptococci oral colonization in 12-30-month-old Brazilian children over a one year followup period. J Public Health Dent. 61:161-167. doi:http:// dx.doi.org/10.1111/j.1752-7325.2001.tb03384.x

Mattos-Graner RO, Klein MI, Smith DJ. 2014. Lessons learned from clinical studies: roles of mutans streptococci in the pathogenesis of dental caries. Curr. Oral Health:70-78. REP. 1.

Mattos-Graner RO, Napimoga MH, Fukushima K, Duncan MJ, Smith DJ. 2004. Comparative analysis of Gtf isozyme production and diversity in isolates of Streptococcus mutans with different biofilm growth phenotypes. J Clin 
Microbiol. 42:4586-4592. doi:http://dx.doi.org/10.1128/ JCM.42.10.4586-4592.2004

Mattos-Graner RO, Zelante F, Line RC, Mayer MP. 1998. Association between caries prevalence and clinical, microbiological and dietary variables in 1.0 to 2.5 -yearold Brazilian children. Caries Res. 32:319-323. doi:http:// dx.doi.org/10.1159/000016466

Mccormick TS, Weinberg A. 2010. Epithelial cell-derived antimicrobial peptides are multifunctional agents that bridge innate and adaptive immunity. Periodontol. 2000 (54):195-206. doi:http://dx.doi.org/10.1111/j.1600-0757. 2010.00373.x

Montreekachon P, Nongparn S, Sastraruji T, Khongkhunthian S, Chruewkamlow N, Kasinrerk W, Krisanaprakornkit S. 2014. Favorable interleukin-8 induction in human gingival epithelial cells by the antimicrobial peptide LL-37. Asian Pac J Allergy Immunol. 32:251-260. doi:http://dx.doi. org/10.12932/AP0404.32.3.2014

O'Sullivan DM, Tinanoff N. 1996. The association of early childhood caries patterns with caries incidence in preschoolchildren. J Public Health Dent. 56:81-83. doi:http:// dx.doi.org/10.1111/j.1752-7325.1996.tb02401.x

Ouhara K, Komatsuzawa H, Yamada S, Shiba H, Fujiwara T, Ohara M, Sayama K, Hashimoto K, Kurihara H, Sugai M. 2005. Susceptibilities of periodontopathogenic and cariogenicbacteria to antibacterial peptides, \{beta\}-defensins and LL37, produced by human epithelial cells. J Antimicrob Chemother. 55:888-896. doi:http://dx.doi.org/10.1093/jac/ dki103

Reynolds NL, De Cecco M, Taylor K, Stanton C, Kilanowski F, Kalapothakis J, Seo E, Uhrin D, Campopiano D, Govan J, et al. 2010. Peptide fragments of a beta-defensin derivative with potent bactericidal activity. Antimicrob Agents Chemother. 54:1922-1929. doi:http://dx.doi.org/10.1128/ AAC.01568-09

Rocha Rdos S, Meireles JR, de Moraes Marcílio Cerqueira E.. 2014. Chromosomal damage and apoptosis analysis in exfoliated oral epithelial cells from mouthwash and alcohol users. Genet Mol Biol. 37:702-707. doi:http://dx.doi.org/ $10.1590 /$ S1415-47572014005000022
Sahl HG, Pag U, Bonness S, Wagner S, Antcheva N, Tossi A. 2005. Mammalian defensins: structures and mechanism of antibiotic activity. J Leukoc Biol. 77:466-475. doi:http:// dx.doi.org/10.1189/jlb.0804452

Sansone C, van Houte J, Joshipura K, Kent R, Margolis HC. 1993. The association of mutans streptococci and nonmutans streptococci capable of acidogenesis at a low $\mathrm{pH}$ with dental caries on enamel and root surfaces. J Dent Res. 72:508-516. doi:http://dx.doi.org/10.1177/00220345930720 020701

SB Brasil. Brazilian. Oral Health. Report. 2010. Available at: http://dab.saude.gov.br/CNSB/sbbrasil/arquivos/projeto_ sb2010_relatorio_final.pdf. [Published: 30th Dec. 2015].

Stewart PS. 2015. Antimicrobial tolerance in biofilms. Microbiol Spectr. 3. doi:http://dx.doi.org/10.1128/microbiolspec. MB-0010-2014

Tong Z, Zhou L, Jiang W, Kuang R, Li J, Tao R, Ni L. 2011. An in vitro synergetic evaluation of the use of nisin and sodium fluoride or chlorhexidine against Streptococcus mutans. Peptides. 32:2021-2026. doi:http://dx.doi.org/10.1016/j. peptides.2011.09.002

van Houte J, Lopman J, Kent R. 1996. The final pH of bacteria comprising the predominant flora on sound and carious human root and enamel surfaces. J Dent Res. 75: 1008-1014. doi:http://dx.doi.org/10.1177/0022034596075 0040201

van Houte J, Sansone C, Joshipura K, Kent R. 1991. In vitro acidogenic potential of mutans streptococci of human smooth-surface plaque associated with initial caries lesions and sound enamel. J Dent Res. 7:1497-1502.

Vandamme D, Landuyt B, Luyten W, Schoofs L. 2012. A comprehensive summary of LL-37, the factotum human cathelicidin peptide. Cell Immunol. 280:22-35. doi:http:// dx.doi.org/10.1016/j.cellimm.2012.11.009

Wiesner J, Vilcinskas A. 2010. Antimicrobial peptides - the ancient arm of the human immune system. Virulence. 1:440-464. doi:http://dx.doi.org/10.4161/viru.1.5.12983

Yeaman MR, Yount NY. 2003. Mechanisms of antimicrobial peptide action and resistance. Pharmacol Rev. 55:27-55. doi:http://dx.doi.org/10.1124/pr.55.1.2 